\title{
教育社会学と政治思想, それからフィールドワーク
}

宇野 重規

私は西洋政治思想史の研究者である。その意味で, 教育社会学会の会員に対し何 らかのメッセージを送ることは，ひどく場違いなことにも思える。しかしながら， 振り返ってみると, 私の研究と教育社会学との間に, まったく接点がないというわ けではない。というのも, 私の専門とする政治思想史研究において「教育」は極め て重要なテーマであり, しかも思想史研究者である私は, 同時にフィールドワーク を好み，思想と社会調査の架橋に大きな関心を持っているからである。そのような 視点から, 教育社会学と政治思想, そしてフィールドワークと, いささか三題噺の ような内容を，以下に記してみたいと思う。

\section{1. トクヴィル『アメリカのデモクラシー』}

最初に, 私の研究の話をしておきたい。私は19世紀フランスの思想家アレクシ・ ド・トクヴィル（1805-59）の研究をしている。トクヴィルは古い名門貴族の家系 に生れたにもかかわらず，アメリカのデモクラシーに関心を持つようになる。9ケ 月ほどの現地調查を行った後, 1835年に『アメリカのデモクラシー』第 1 巻を, そ の 5 年後に第 2 巻を刊行した。この著作はアメリカ論の古典としてのみならず，お よそデモクラシーに関心を持つ人間にとっての必読書として, 現在も読み継がれて いる(1)

興味深いのは，なぜトクヴィルが，けっして交通手段も整っていなかったこの時 代にあって, 当時新大陸と呼ばれたアメリカの各地を巡り, 現地調査を行ったのか, ということである。すでに触れたように，トクヴィルは古い貴族の家で育った。父

東京大学 
や母を含め，多くの親族がフランス革命で傷つき， 革命やデモクラシーに対して深 い敵意を持っていた（危うくギロチンにかけられそうになったトクヴィルの父親は, 一晚にしてその髪が真っ白になり，精神を病んだ母親は，旧き宮廷社会の追憶の中 に生き続けたという)。それなのにトクヴィルは, あえてデモクラシーとは何かに 興味を抱き，しかも遠いアメリカにまで旅立ったのである。それが並外れた勇気を 必要とするものであったことは想像に難くない。

トクヴィルは心の中で, 古い貴族の時代が終わり, 平等化が進む時代の到来しつ つあることを感じていた。しかしながら,「デモクラシーは正しい」というばかり では，家族を説得することはできない。彼自身，「貴族やエリートではなく，普通 の人々が社会を運営し, 統治を行うことができるのだろうか」という疑問もあった。 そこでトクヴィルは，自らアメリカを訪れて，そこでのデモクラシーの実際を探っ てみようと決意したのである。

トクヴィルのアメリカ観が定まったのは, ボストン周辺のタウンシップと呼ばれ る，基礎的な自治体における聞き取り調査の結果である。ここで彼は，人々が地域 の自治に参加し, 学校や病院, 道路や橋などを中央政府の力を借りることなく, 自 ら計画して建設している様子に強い印象を受けた。彼らは地域の実情をよく知り, かつ地域の問題に自ら取り組んでいる。結果として, 人々の政治的意識は高く, 公 共的関心も強いことを知ったのである。

祖国フランスでは，革命後にむしろ中央集権化が進み，人々の政府に対する依存 心が強まっているのと比べ，なぜアメリカでは人々の自立心が旺盛で, 自主的に社 会を運営する気風が強いのか。この問題を考えたトクヴィルが行き着いたのは，政 治参加の重要であった。地方自治, 陪審, そして多様なアソエーションの活動を通 じて, アメリカの人々は政治に参加している。そして, そのことによって, アメリ カのデモクラシーは健全なものとして維持されている。トクヴィルはそのように確 信したのである。デモクラシーがつねに正しいとは限らないが，一定の社会的条件 の下では, 健全に営まれる。このような彼の結論が後世に大きな影響を与えたので ある。

\section{2. 政治思想と教育}

このようなトクヴィルを，ジャン＝ジャック・ルソー（1712-78）と対比してみ ると興味深い。ルソーはトクヴィルより100年ほど前の人物であるが, その著作 『人間不平等起源論』や『社会契約論』は, フランス革命に対して巨大な影響を及 
ぼしたと言われている。トクヴィルもまた, ルソーの著作を繰り返し読み, そこか ら自らの思考の糧を得た一人であった。トクヴィルにとってルソーの人民主権論は 魅力的なものであったが, フランス結果が恐怖政治をもたらしたことからもうかが えるように，その議論にはどこか不安定なものがあるように思えた。

ちなみにルソーは『社会契約論』とまったく同じ1762年に, 教育学の古典とされ る『エミール』を刊行している。ルソーにとって，政治と教育は良き市民を育てる という点では課題を同じくするものであった。このような考え方は, けっしてル ソーの独創ではない。古くはプラトンが『国家』において，良き統治と良き市民の 育成の不可分を説いている。その後, 『統治二論』で知られているジョン・ロック も, 教育学の重要な著作を残している。その意味では, 偉大な政治思想家が偉大な 教育学の著作を残すという伝統が, この二世紀ほど, あまり見られないのは残念な ことである。ジョン・デューイは，数少ない例外かもしれない。

ルソーは『社会契約論』と『エミール』において, 理想の政治と教育の可能性を 追求した。その模索が真摰なものであったこと, そしてその論理が鋭く, かつ大き な影響力を持つものであったことは強調するまでもない。しかしながら，その思考 はややもすれば仮想実験的になったことも事実である。古代ギリシアやローマの歴 史, 近代におけるヨーロッパ各国における多様な実践, さらにはルソー自身の経験 が踏まえられているとはいえ, 彼の思考はどうしても抽象的となりがちであった。

このようなルソーと比べるならば, トクヴィルはルソーから大きなインスピレー ションを得つつも, アメリカという現実の場所における調査によって，デモクラ シーの現実的な機能とその条件を探ったと言えるだろう。20世紀フランスを代表す る哲学者であり, 社会学者でもあったレイモン・アロンは, トクヴィルを「社会学 的思考の源流」と見なしているが，その議論には説得力があると思われる ${ }^{(2)}$ 。

\section{3. フィールドワーク}

偉大な政治思想家であるトクヴィルに自分をなぞらえるのは不遜であるが，私も 早くから地域調査に関心を持ってきた。

トクヴィルは『アメリカのデモクラシー』の冒頭で,「私はアメリカで, アメリ カ以上のものを見た」と記している。いわば，彼はアメリカで，人類が向かうべき 平等社会の理想と現実を見出したと言える。しかしながら, トクヴィルに洞察を与 えたのが,アメリカでの現地調査であったことは間違いない。アメリカの地におけ る実践を見ることなしに，あの名著が生まれたとは思えない。 
私もまた, 所属する東京大学社会科学研究所における「希望学」という研究プロ ジェクトに参加し，その一環として岩手県釜石市における現地調査を行ってきた。 人が希望を持ったり，持たなかったりするのは，個人の心の問題なのか。あるいは むしろ，多様な社会的要因が，そこに反映されているのではないか。さらには，地 域社会における希望の所在を決定するのは, いかなる要因か。このような研究を製 鉄で知られる釜石の街で考えようとしたのである。

もちろん，あくまで思想史研究者としてのトレーニングしか受けていない私に， フィールドワークを行うための知識や能力があったわけではない。すべてはその場 におけるOJTであり，あるいはお話を伺った釜石のみなさんに対し，不㷣な質問 をしたりしたことがあったかもしれない。

とはいえ, この釜石における地域調査を通じて, 現代日本の地域社会における 人々の社会つながり, 歴史や伝統との関わり, そして地域の变革に対する取り組み を実感することができた。私は，まさにトクヴィルが200年前にしたことを，現代 日本において真似しようとしたのかもしれない。それが単なる真似ごとで終わった としても，古典のテクストだけを読んで地方自治やデモクラシーを考えていただけ では得られなかった視点を獲得できたと実感している。フィールドワークは偉大で ある。今後も私は,「旅する政治思想史研究者」でありたいと願っている。

\section{4. 教育社会学への期待}

最後に教育社会学への期待を申し上げたい。すでに指摘したように，政治研究と 教育研究とは, 多くの主題を共有している。にもかかわらず, 現状において両者の 交流は政治教育の分野などを除くと，あまり活発ではない。実証的な政治学の研究 と, 教育をめぐる社会学的な研究の相性もいいとは言えない。しかしながら, 今後, 両者の結びつきを深めることは，双方にとって利点があると言えるのではないか。

著者に身近なトクヴィルをとってみても, 彼にとって最大の主題であったのは平 等化の問題であった。かつての身分制社会とは異なり，民主的な社会においては平 等化が進行する。このことは政治に対して，いかなる影響を及ぼすのだろうか。個 人主義的な思考の発展, 伝統的な社会的紐帯の喪失, さらには教育の場における権 威の消滅など, トクヴィルが指摘した論点の多くは, 教育と格差の問題に関心を持 つ教育社会学者にとっても重要な意味を持っているのではなかろうか ${ }^{(3)}$ 。

トクヴィルがいう「個人主義」とは，伝統から切り離された個人が，自分とその 狭い世界に閉じ达められ，他者の結びつきを失い，孤立することを指す。トクヴィ 
ルがこの言葉を用いたのは19世紀の前半であるが，不思議と現代日本の若者を思わ せる部分がある。トクヴィルによれば，そのような個人は，すべてを自分で判断し たいと願いつつ，世の中の流行や動向に強く影響される。その孤立はけっして社会 に対する無関心を意味するのではなく，むしろ社会に対する焦燥感に似た関心と不 可分なのである。このようなトクヴィルの「個人主義」論は, ある意味で, 現代日 本で「引きこもり」とされる若者を想起させるだろう。

その意味で, トクヴィルの「個人主義」を媒介に, 政治思想研究と教育社会学と を架橋することは，けっして不可能ではない。それだけではない。トクヴィルの指

摘する家庭や教育の場における権威の消滅も，教育社会学と無関係ではないだろう。 その根拠を問うことなしに人々が従うものを権威と呼ぶならば，そのような権威は 民主的社会においては次第に失われていく。教師と学生, 親と子も, 次第に権威に 基づく関係から, 対等な人間の関係へと移り変わっていくと, トクヴィルは予言し た。しかしながら，すべての権威が失われるとき，社会は本当に成り立つのだろう か。トクヴィルの問題提起は，現代日本においてこそ，あらためて問い直されるべ きだろう。

ことほど左様に, 政治思想研究と教育社会学との間には接点がある。理念と社会 の実態の間を往復しながら, 個人と社会の行方を展望するという意味で, 両者は深 く関わっていると言えるだろう ${ }^{(4)}$ 。

おそらく政治思想研究と教育社会学の原点にあるのは，ともに「旅」なのではな いか。異なる場所において，異なる暮らし方をする人々の間にあって，およそ政治 や教育の本質を探ることは，まさに「旅」である。フィールドワークとは現代にお ける「旅」に他ならない。「旅する政治思想研究者」と教育社会学との間には, い ろいろなコラボレーションがありうると思うのだが, どうだろうか。

\section{【注】}

(1)『アメリカのデモクラシー』については，現在，岩波文庫で読むことができる。 松本礼二訳，岩波文庫，全四巻，2005-2008年。

(2) レイモン・アロン『社会学的思考の流れ』北川隆吉訳, 法政大学出版局, 1974年。

（3）これらの論点につき, 拙著『トクヴィル 平等と不平等の理論家』講談社選書 メチエ, 2007年を参照。

（4）筆者による試みとして,「〈私〉時代の教育と政治」, 宇野重規・井上彰・山崎 望編『実践する政治哲学』, ナカニシヤ出版, 2012年 3 月, pp.35-61がある。 